\title{
PENGARUH MODEL COOPERATIVE SCRIPT TERHADAP AKTIVITAS DAN HASIL BELAJAR BIOLOGI SISWA KELAS VIII SMP NEGERI 7 LUBUKLINGGAU
}

\author{
Zico Fakhrur Rozi ${ }^{1}$, Harmoko $^{2}$, Ferty Lia Teresa ${ }^{3}$ \\ STKIP PGRI Lubuklinggau ${ }^{1,2,3}$ \\ Zico.fakhrurrozi@gmail.com ${ }^{1}$
}

\begin{abstract}
ABSTRAK
Penelitian ini bertujuan untuk melihat pengaruh model Cooperative Script terhadap aktivitas dan hasil belajar biologi siswa kelas VIII SMP Negeri 7 Lubuklinggau. Teknik pengumpulan data untuk hasil belajar menggunakan teknik tes, sedangkan data aktivitas belajar menggunakan teknik observasi. Nilai rata-rata siswa untuk kelas yang diajarkan dengan model Cooperative Script sebesar 70,11, sedangkan untuk kelas yang diajarkan dengan menggunakan pembelajaran konvensional sebesar 64,22. Data yang terkumpul dianalisis menggunakan uji-t pada taraf signifikan $\alpha=0,05$ maka diperoleh $(2,45)>(1,67)$, ada pengaruh model Cooperative Script terhadap hasil belajar biologi siswa kelas VIII SMP Negeri 7 Lubuklinggau. Hasil observasi aktivitas belajar pertemuan pertama diperoleh nilai rata-rata sebesar $75,33 \%$ dengan kategori cukup dan hasil observasi aktivitas belajar pertemuan kedua diperoleh nilai rata-rata sebesar 75,94\% dengan kategori cukup, yang berarti aktivitas belajar biologi siswa kelas VIII SMP Negeri 7 Lubuklinggau lebih meningkat setelah diberikan perlakuan dengan menggunakan model Cooperative Script. Simpulan, model cooperative script berpengaruh secara signifikan secara statistik terhadap peningkatan aktivitas dan hasil belajar biologi siswa kelas VIII SMP Negeri 7 Lubuklinggau.
\end{abstract}

Kata Kunci: aktivitas belajar, hasil belajar, model cooperative script

\section{ABSTRACT}

This study aims to see the effect of the Cooperative Script model on the activities and learning outcomes of biology students of class VIII of SMP Negeri 7 Lubuklinggau. Data collection techniques for learning outcomes use test techniques, while learning activity data use observation techniques. The average value of students for classes taught by Cooperative Script models is 70.11, while for classes taught using conventional learning is 64.22. The collected data were analyzed using t-test at a significant level $\alpha=0.05$ then obtained (2.45)> (1.67), there was an effect of the Cooperative Script model on biology learning outcomes of Grade VIII students of SMP Negeri 7 Lubuklinggau. The results of observations of the learning activities of the first meeting obtained an average value of $75.33 \%$ with enough categories and the results of observations of the learning activities of the second meetings obtained an average value of $75.94 \%$ with enough categories, which means biology learning activities for VIII grade students of SMP Negeri 7 Lubuklinggau is further improved after being treated using the Cooperative Script model. In conclusion, the cooperative script model has a 
statistically significant effect on increasing the activities and learning outcomes of biology students in grade VIII of SMP Negeri 7 Lubuklinggau.

Keywords: learning activities, learning outcomes, cooperative script models

\section{PENDAHULUAN}

Pendidikan merupakan faktor utama dalam memperbaiki sumber daya manusia (SDA). Pendidikan yang baik harus dilakukan secara terencana sehingga dapat mewujudkan suasana belajar dan proses pembelajaran secara aktif dan siswa mampu mengembangkan potensi dirinya untuk memiliki kekuatan spiritual keagamaan, pengendalian diri, kepribadian, kecerdasan ahklak mulia, serta keterampilan yang diperlukan untuk pribadi dan masyarakat (Sugiyanto, 2010). Pembelajaran Ilmu Pengetahuan Alam (IPA) pada dasarnya berupa fakta, konsep, prinsip dan teori-teori. Sesungguhnya Ilmu Pengetahuan Alam (IPA) merupakan ilmu yang memerlukan pemahaman dan evaluasi atau berpikir tingkat tinggi. Oleh karena itu, guru perlu menggunakan berbagai model pembelajaran dalam proses belajar mengajar.

Guru memiliki tanggung jawab atas pengelolaan sistem perencanaan dan pelaksanaan pembelajaran dan harus berusaha untuk mencapai tujuan pembelajaran dengan cara menggunakan model pembelajaran yang tepat. Pada proses belajar-mengajar, guru harus memiliki berbagai model mengajar yang dapat memotivasi peran aktif siswa, agar dapat belajar secara efektif dan efisien, tepat pada tujuan yang diharapkan (Sumiati, 2009). Penggunaan model pembelajaran yang kurang melibatkan siswa secara aktif, terpusat pada guru, cenderung monoton sehingga dapat mempengaruhi hasil belajar siswa.

Berdasarkan hasil observasi awal pada tanggal 17 Maret 2017 dengan melakukan wawancara kepada guru bidang studi Ilmu Pengetahuan Alam (IPA) yang mengajar bioogi di SMP Negeri 7 Lubuklinggau, diperoleh hasil bahwa nilai rata-rata hasil belajar ulangan harian siswa kelas VIII pada mata pelajaran Ilmu Pengetahuan Alam (IPA) sebesar 65,24. Hal ini menunjukkan bahwa hasil belajarnya yang di bawah Kriteria Ketuntasan Minimal (KKM) yaitu 75 dengan rincian 117 siswa $(46,43 \%)$ yang tuntas dan 135 siswa $(53,57 \%)$ belum tuntas dengan jumlah keseluruhan siswa 252 orang. Rendahnya hasil belajar siswa kelas VIII SMP Negeri 7 Lubuklinggau disebabkan kurangnya aktivitas siswa dalam proses pembelajaran sehingga berakibat pada hasil belajar siswa.

Kurangnya aktivitas siswa dilihat dari perilaku siswa dalam belajar yang tidak berani dalam mengeluarkan pendapat, menjawab pertanyaan, bahkan untuk bertanya kepada guru saat belajar. Selain itu, siswa kurang mempunyai keinginan untuk terlibat secara aktif dalam proses pembelajaran, siswa cenderung hanya menunggu materi yang disampaikan oleh guru tanpa adanya inisiatif untuk mencari dan menggali sendiri informasi secara mandiri sebelum materi tersebut disajikan. Hal ini sesuai dengan pendapat Purwanto (2012) kebiasaan siswa yang 
cenderung hanya menunggu materi yang disampaikan oleh guru membuat siswa kesulitan dalam memahami konsep-konsep yang telah dipelajari yang pada akhirnya mengakibatkan hasil belajar siswa tidak sesuai dengan yang diharapkan.

Salah satu alternatif untuk mengatasi permasalahan di atas yaitu dengan menggunakan model pembelajaran yang dapat memotivasi dan membuat siswa aktif serta menyenangkan dalam proses belajar mengajar. Salah satu model yang sesuai yaitu model Cooperative Script. Menurut Aqib (2013) model Cooperative Script disebut juga Skrip kooperatif yaitu model belajar di mana siswa bekerja berpasangan dan secara lisan mengikhtisarkan bagian-bagian dari materi yang dipelajarinya dalam ruangan kelas.

Dapat disimpulkan jika model Cooperative Script adalah model pembelajaran yang dapat meningkatkan daya ingat siswa. Hal tersebut sangat membantu siswa dalam mengembangkan serta mengaitkan fakta-fakta dan konsep-konsep yang pernah didapatkan dalam pemecahan masalah. Pada penelitian ini juga dikembangkan lembar kegiatan siswa sehingga mempermudah siswa dalam menerima materi dan menjadi pembeda dengan penelitian sebelumnya. Adapun, penelitian ini bertujuan untuk melihat pengaruh model Cooperative Script terhadap aktivitas dan hasil belajar biologi siswa kelas VIII SMP Negeri 7 Lubuklinggau.

\section{METODE PENELITIAN}

\section{Rancangan Penelitian}

Jenis penelitian ini adalah eksperimen murni, yang terdiri dua kelompok sampel yaitu satu kelompok eksperimen yang diberi pelakuan model Cooperative Script dan satu kelompok kontrol yang diberi pembelajaran konvensional. Sebelum mengadakan eksperimen dilakukan pre-test pada kelas eksperimen dan kelas kontrol. Setelah pemberian perlakuan (treatment), kemudian diadakan posttest pada kelas eksperimen pada kelas kontrol. Desain eksperimen yang digunakan berbentuk Control group pre-test-pos-test Arikunto (2010) dapat digambarkan pada tabel 1:

Tabel 1. Desain Control Group Pre-Test-Pos-Test

\begin{tabular}{cccc}
\hline Kelas & Pre-Test & Treatment & Post-Test \\
\hline $\mathrm{E}$ & $\mathrm{O}_{1}$ & $\mathrm{X}$ & $\mathrm{O}_{2}$ \\
\hline $\mathrm{K}$ & $\mathrm{O}_{3}$ & - & $\mathrm{O}_{4}$ \\
\hline
\end{tabular}

Keterangan:

E : Kelas Eksperimen

K : Kelas Kontrol

$\mathrm{O}_{1}$ dan $\mathrm{O}_{3}$ : Pre-testdi kelas eksperimen dan kontrol

$\mathrm{X} \quad$ : Perlakuan dengan menerapkan modelCooperative Script

: Perlakuan dengan menerapkan pembelajaran konvensional 
$\mathrm{O}_{1}$ dan $\mathrm{O}_{3}$ : Post-test di kelas eksperimen dan kontrol

\section{Populasi dan Sampel}

Populasi dalam penelitian ini adalah semua siswa kelas VIII SMP Negeri 7 Lubuklinggau tahun ajaran 2017/2018 sebanyak 252orang yang terdiri dari 7 kelas. Populasi penelitian dapat dilihat pada tabel 2 berikut ini.

Tabel 2. Populasi Penelitian

\begin{tabular}{ccccc}
\hline No. & Kelas & Laki-laki & Perempuan & Jumlah \\
\hline 1 & VIII.1 & 17 & 20 & 37 \\
\hline 2 & VIII.2 & 17 & 18 & 35 \\
\hline 3 & VIII.3 & 19 & 17 & 36 \\
\hline 4 & VIII.4 & 17 & 19 & 36 \\
\hline 5 & VIII.5 & 17 & 19 & 36 \\
\hline 6 & VIII.6 & 10 & 25 & 35 \\
\hline 7 & VIII.7 & 16 & 21 & 37 \\
\hline & Jumlah & 113 & 139 & 252
\end{tabular}

Sumber: Tata Usaha SMP Negeri 7 Lubuklinggau

Sampel penelitian ini diambil dengan cara acak atau random. Berdasarkan hasil pengundian, maka ditetapkan kelas VIII.3 yang berjumlah 36 siswa sebagai kelas eksperimen dan kelas VIII.4 yang berjumlah 36 siswa sebagai kelas kontrol. Sampel penelitian dapat dilihat pada Tabel 3 sebagai berikut:

Tabel 3. Sampel Penelitian

\begin{tabular}{cccccc}
\hline No & Kelas & Laki-laki & Perempuan & Jumlah & Keterangan \\
\hline 1 & VIII.3 & 19 & 17 & 36 & Kelas Eksperimen \\
\hline 2 & VIII.4 & 17 & 19 & 36 & Kelas Kontrol \\
\hline & Jumlah & 36 & 36 & 72 & \\
\hline
\end{tabular}

\section{Teknik Pengumpulan Data}

Teknik pengumpulan data yang digunakan dalam penelitian ini adalah teknik tes dengan menggunakan instrumen berbentuk tes pilihan ganda dan teknik observasidengan menggunakan instrumen berbentuk lembar observasi.

\section{Teknik Tes}

Pengumpulan data hasil belajar dalam penelitian ini menggunakan instrumen berbentuk tes pilihan ganda. Arikunto (2010) menyatakan bahwa "tes adalah serentetan pertanyaan atau latihan serta alat lain yang digunakan untuk mengukur keterampilan, pengetahuan intelegensi, kemampuan atau bakat yang dimiliki oleh individu atau kelompok". Tes ini berbentuk pilihan ganda yang diberikan sebanyak dua kali yaitu sebelum (pre-test) dan sesudah (post-test) yang masing-masing diberikan di kelas eksperimen dan kontrol. Pre-test diberikan untuk melihat kemampuan awal siswa dan post-test diberikan untuk memperoleh 
data tentang hasil belajar siswa atau kondisi akhir.Hasil belajar yang diukur dalam ranah kognitif dalam materi struktur dan fungsi jaringan tumbuhan melalui tes pilihan ganda berjumlah 21 soal.

\section{Teknik Observasi}

Pengumpulan data observasi dalam penelitian ini menggunakan instrumen berbentuk lembar observasi.Menurut Arikunto (2010) “observasi atau pengamatan merupakan kegiatan pemusatan terhadap suatu objek dan menggunakan seluruh alat indera. Mengukur data aktivitas siswa menggunakan lembar observasi, kegiatan observasi dilaksanakan pada saat proses pembelajaran menggunakan model Cooperative Script dengan mengajak 4 teman sejawat sebagai observer.

\section{Teknik Analisis Data}

Teknik analisis data dalam penelitian ini adalah analisis data tes hasil belajar dan data lembar observasi.

\section{Uji Hipotesis}

Jika kedua kelas data berdistribusi normal dan homogen, maka uji statistik yang digunakan adalah uji-t dengan rumus:

$$
\mathrm{t}=\frac{\bar{x}_{1}-\bar{x}_{2}}{s \sqrt{\frac{1}{n_{1}}+\frac{1}{n_{2}}}} \text { dengan } S^{2}=\frac{\left(n_{1}-1\right) s_{1}+\left(n_{2}-1\right) S_{2}^{2}}{n_{1}+n_{2}-2}(\text { Sudjana, 2005) }
$$

Keterangan:

$\bar{x}_{1}=$ nilai rata-rata post-testkelas eksperimen

$\bar{x}_{2}=$ nilai rata-rata post-testkelas kontrol

$n_{1}$ = banyaknya sampel kelas eksperimen

$n_{2}=$ banyaknya sampel kelas kontrol

$S_{1}^{2}=$ varians terbesar

$S_{2}^{2}=$ varians terkecil

Kriteria pengujiannya ialah terima $H_{0}$ jika $t_{\text {hitung }}<t_{\text {tabel }}$ pada taraf kepercayaan $\alpha=0,05$ dan $\mathrm{dk}=\left(n_{1}+n_{2}-2\right)$

\section{Lembar Observasi}

Aktivitas belajar siswa diukur dengan menggunakan lembar observasi. Teknik analisis data aktivitas belajar menggunakan rumus:

$\mathrm{NP}=\frac{R}{S M} \times 100 \%$ dengan $\mathrm{R}=\frac{\sum S T}{N}($ Purwanto, 2012)

\section{Dimana:}

$\mathrm{NP}=$ Nilai persen aktivitas belajar

$\mathrm{R} \quad=$ Skor rata-rata aspek aktivitas belajar

$\mathrm{SM}=$ Skor maksimum ideal dari aspek aktivitas belajar

$\sum \mathrm{ST}=$ Jumlah skor total dari aspek aktivitas belajar

$\mathrm{N} \quad=$ Banyaknya jumlah subjek 
Interprestasi nilai presentase aktivitas belajar siswa menurut Purwanto (2012) dibagi ke dalam kategori-kategori sebagai berikut:

Tabel 4. Interprestasi Nilai Persen Aktivitas Belajar

\begin{tabular}{c|c}
\hline Nilai & Interprestasi \\
\hline $86 \%<\mathrm{NP} \leq 100 \%$ & Sangat Baik \\
\hline $76 \%<\mathrm{NP} \leq 85 \%$ & Baik \\
\hline $60 \%<\mathrm{NP} \leq 75 \%$ & Cukup \\
\hline $55 \%<\mathrm{NP} \leq 59 \%$ & Kurang \\
\hline $\mathrm{NP} \leq 54 \%$ & Sangat Kurang \\
\hline
\end{tabular}

\section{HASIL PENELITIAN}

Hasil Belajar

Deskripsi Kemampuan Awal Siswa

Tabel 5. Uji Kesamaan Dua Rata-rata Pre-Test

\begin{tabular}{ccccc}
\hline Tes & $\mathbf{t}_{\text {hitung }}$ & Derajat Kebebasan (Dk) & $\mathbf{t}_{\text {tabel }}$ & Kesimpulan \\
\hline Pre-Test & $-3,95$ & 60 & 2,00 & $-2,00<-3,95<2,00, H_{0}$ diterima \\
\hline
\end{tabular}

Berdasarkan pernyataan di atas, dapat ditarik kesimpulan bahwa hasil uji kesamaan dua rata-rata data pre-test menunjukan bahwa rata-rata hasil belajar kelas eksperimen sama dengan rata-rata kelas kontrol.

\section{Deskripsi Kemampuan Akhir Siswa}

Hasil perhitungan uji kesamaan rata-rata post-test pada kelas eksperimen dan kontrol, diperoleh nilai $t_{\text {hitung }}=2,45$ dan $t_{\text {tabel }}=1,68$ menunjukan bahwa $t_{\text {hitung }}$ $>\mathrm{t}_{\text {tabel }}$ dengan taraf kepercayaan $\alpha=0,05$, maka $\mathrm{H}_{\mathrm{a}}$ ditolak dan $\mathrm{H}_{0}$ diterima, berarti rata-rata hasil belajar kelas eksperimen lebih dari rata-rata kelas kontrol.

Tabel 6. Uji Kesamaan Rata-rata

\begin{tabular}{ccccc}
\hline Tes & $\mathbf{t}_{\text {hitung }}$ & Derajat Kebebasan(Dk) & $\mathbf{t}_{\text {tabel }}$ & Kesimpulan \\
\hline Post-Test & 2,45 & 40 & 1,67 & $2,45>1,67, H_{a}$ diterima \\
\hline
\end{tabular}

Berdasarkan pernyataan di atas, diketahui bahwa hasil perhitungan uji kesamaan dua rata-rata data post-test menunjukan bahwa rata-rata hasil belajar kelas eksperimen lebih dari rata-rata kelas kontrol. Maka dapat ditarik kesimpulan ada pengaruh model Cooperative Script terhadap hasil belajar biologi siswa kelas VIII SMP Negeri 7 Lubuklinggau. 


\section{Aktivitas Belajar}

Data observasi dalam penelitian ini diperoleh dengan melakukan kegiatan observasi menggunakan instrumen berbentuk lembar observasi yang dilakukan pada siswa kelas di kelas VIII.3 SMP Negeri 7 Lubuklinggau. Adapun aspekaspek aktivitas belajar siswa yang dianalisis yaitu aspek memperhatikan apa yang disampaikan guru, menjawab pertanyaan guru, membaca LKS yang diberikan guru, meringkas LKS yang diberikan guru, bekerja sama dengan teman pasangan, mempresentasikan hasil ringkasan LKS kepada teman pasangan, dan menanggapi hasil ringkasan LKS yang disampaikan teman pasangan Kegiatan observasi dilaksanakan saat proses pembelajaran menggunakanmodel Cooperative Script pada kelas eksperimen di pertemuan pertama dan kedua. Hasil perhitungan lembar observasi aktivitas belajar kelas eksperimen pertemuan pertama dan kedua sebagai berikut:

Tabel 7. Persentase Aktivitas Belajar pada Pertemuan Pertama

\begin{tabular}{clcl}
\hline No & \multicolumn{1}{c}{ Aspek Aktivitas Belajar } & Nilai (\%) & Kategori \\
\hline 1 & Memperhatikan apa yang disampaikan guru & $76 \%$ & Baik \\
\hline 2 & Menjawab pertanyaan guru & $77 \%$ & Baik \\
\hline 3 & Membaca LKS yang diberikan guru & $71 \%$ & Cukup \\
\hline 4 & Meringkas LKS yang diberikan guru & $73 \%$ & Cukup \\
\hline 5 & Bekerja sama dengan teman pasangan & $77 \%$ & Baik \\
\hline 6 & $\begin{array}{l}\text { Mempresentasikan hasil ringkasan LKS kepada teman } \\
\text { pasangan }\end{array}$ & $76 \%$ & Baik \\
\hline 7 & $\begin{array}{l}\text { Menanggapi hasil ringkasan LKS yang disampaikan teman } \\
\text { pasangan }\end{array}$ & $79 \%$ & Baik \\
\hline & Rata-rata & 75,33 & Cukup \\
\hline
\end{tabular}

Tabel 8. Persentase Aktivitas Belajar pada Pertemuan Kedua

\begin{tabular}{clcl}
\hline No & \multicolumn{1}{c}{ Aspek Aktivitas Belajar } & Nilai (\%) & Kategori \\
\hline 1 & Memperhatikan apa yang disampaikan guru & $72 \%$ & Cukup \\
\hline 2 & Menjawab pertanyaan guru & $75 \%$ & Cukup \\
\hline 3 & Membaca LKS yang diberikan guru & $76 \%$ & Baik \\
\hline 4 & Meringkas LKS yang diberikan guru & $81 \%$ & Baik \\
\hline 5 & Bekerja sama dengan teman pasangan & $74 \%$ & Cukup \\
\hline 6 & $\begin{array}{l}\text { Mempresentasikan hasil ringkasan LKS kepada teman } \\
\text { pasangan }\end{array}$ & $77 \%$ & Baik \\
\hline 7 & $\begin{array}{l}\text { Menanggapi hasil ringkasan LKS yang disampaikan teman } \\
\text { pasangan }\end{array}$ & $78 \%$ & Baik \\
\hline & Rata-rata & 75,94 & Cukup \\
\hline
\end{tabular}




\section{PEMBAHASAN}

\section{Hasil Belajar}

Penelitian ini dilaksanakan untuk melihat pengaruh model Cooperative Script terhadap hasil belajar biologi siswa kelas VIII SMP Negeri 7 Lubuklinggau. Hasil tes awal (pre-test) yang telah diperoleh menunjukkan bahwa tidak terdapat perbedaan nilai rata-rata antara kelas eksperimen dan kelas kontrol. Hal ini dibuktikan dari nilai rata-rata pre-test kelas eksperimen sebesar 53,08 dan nilai rata-rata pre-test kelas kontrol sebesar 61,17. Hasil tes awal (pre-test) pada kelas eksperimen dan kelas kontrol dalam materi ekosistem siswa kelas VIII SMP Negeri 7 Lubuklinggau dapat dikatakan masih rendah.

Masih rendahnya hasil belajar siswa pada tes awal (Pre-test) di kelas eksperimen dan kontrol, disebabkan kurangnya pemahaman siswa tentang materi struktur dan fungsi jaringan tumbuhan sehingga siswa yang tidak memahami materi terlihat kesulitan dalam mengerjakan instrumen soal yang diberikan.Hal ini sesuai dengan pendapat Slameto (2010) menyatakan bahwa tanpa penerapan model pembelajaran yang jelas, akan menimbulkan kesulitan bagi siswa dalam memahami konsep materi sehingga dapatlah diprediksi tujuan pembelajaran yang telah ditetapkan sulit tercapai secara optimal. Akibat yang dapat ditimbulkan adalah hasil belajar siswa menjadi kurang maksimal.

Setelah melakukan tes awal (pre-test), peneliti memberikan perlakuan (treatment) pada kelas eksperimen dan kontrol. Kegiatan treatment pada pertemuan pertama di kelas eksperimen dalam materi struktur jaringan tumbuhan dengan menggunakan model Cooperative Script, terdapat beberapa hambatan yang dihadapi siswa sesuai dengan pendapat Natalina (2013), yaitu kondisi kelas menjadi sedikit gaduh, karena siswa belum terbiasa belajar secara berpasangan yang dibentuk, dari 18 pasang siswa yang dibentuk terdapat 13 pasang siswa yang masih kesulitan bekerja sama dan belum tingginya antusias mereka berperang sebagai pembicara dan pendengar. Selain kelemahan yang ditemukan, terdapat pula kelebihan model Cooperative Script yang ditemukan sesuai dengan pendapat Warouw (2014), yaitu mampu membuat siswa lebih aktif dalam mengikuti setiap kegiatan pembelajaran dengan model Cooperative Script dan memberikan kesempatan siswa berperan sebagai pembicara dan pendengar sehingga meningkatkan kemampuan mengungkapkan pendapatnya sehingga meningkatkan hasil belajar siswa menjadi lebih baik.

Kegiatan treatment pada pertemuan kedua di kelas eksperimen dalam materi fungsi jaringan tumbuhan dengan menggunakan model Cooperative Script, hambatan yang dihadapi, yaitu masih terdapat beberapa siswa dalam tiap pasangan yang kurang antusias dalam berperan sebagai pembicara/pendengar dan mengerjakan LKS yang diberikan. Peneliti juga membentuk 18 pasang siswa. Terdapat kemajuan dalam berkerja sama mengerjakan LKS yang diberikan dan berperan sebagai pembicara dan pendengar, karena 16 kelompok belajar sudah dapat bekerja sama dengan baik mengerjakan LKS (Lembar Kerja Siswa) yang 
diberikan dan hanya 1 kelompok belajar yang masih kesulitan bekerja sama mengerjakan LKS (Lembar Kerja Siswa) sehingga guru harus memberikan pendekatan kepada siswa dalam kelompok belajar tersebut untuk meningkatkan motivasi dan kerja sama mereka dalam mengerjakan LKS (Lembar Kerja Siswa) yang diberikan. Hal ini sesuai dengan pendapat Nurhidayati (2013) menjelaskan bahwa model Cooperative Script dalam penerapannya memiliki beberapa hambatan yaitu beberapa siswa dalam pasanganyang kurang antusias dalam berperan sebagai pembicara/pendengar dan mengerjakan LKS yang diberikan.

Setelah diberikan perlakuan pada kelas eksperimen dan kontrol, kemudian peneliti melakukan tes akhir (post-test) pada kelas eksperimen dan kontrol. Bila diuraikan hasil tes materi struktur dan fungsi jaringan tumbuhan siswa setelah diberikan pembelajaran dengan model Cooperative Script (Post-test) di kelas eksperimen lebih meningkat dari hasil tes dengan pembelajaran konvensional pada kelas kontrol dengan nilai rata-rata tes akhir (post-test) yang diperoleh siswa kelas eksperimen adalah 70,11 lebih dari nilai rata-rata hasil tes akhir (post-test) diperoleh siswa kelas kontrol adalah 64,22. Hal ini menunjukkan bahwa selisih peningkatan nilai rata-rata sebesar 5,89.Penggunaan dari model Cooperative Scriptlebih dapat meningkatkan hasil belajar siswa pada materi struktur dan fungsi jaringan tumbuhan di SMP Negeri 7 Lubuklinggau dari pada penggunaan pembelajaran konvensional.Hasil penelitian yang telah diuraikan di atas, relevan dengan penelitianyang pernah dilakukan oleh Hidayat (2012), Fardilah (2013) dan Hasanah (2013 )menunjukan bahwa penerapan model Pembelajaran Cooperative Script dapat meningkatkan hasil belajar biologi siswa

Berdasarkan hasil penelitian ini dan penelitian yang relevan tersebut, maka model Cooperative Scriptdinyatakan mampu meningkatkan hasil belajar biologi menjadi lebih baik. Hal ini sesuai dengan pendapat Boleng (2014) menjelaskan bahwa para guru dapat menggunakan model Cooperative Script sebagai salah satu alternatif yang dapat digunakan dalam pembelajaran materi struktur dan fungsi jaringan tumbuhan atau pada materi biologi lainnya yang sesuai dengan karakteristiknya. Selain itu, upaya mengatasi hambatan-hambatan yang ditemui dengan melakukan persiapan yang lebih matang dan lebih memperhatikan siswa dalam melakukan pengamatan sehingga terkontrol dengan baik.

\section{Aktivitas Belajar}

Penelitian ini juga melihat pengaruh model Cooperative Script terhadap aktivitas belajar biologi siswa kelas VIII SMP Negeri 7 Lubuklinggau. Data aktivitas belajar dalam penelitian ini diperoleh dari hasil kegiatan observasi menggunakan instrumen berbentuk lembar observasi. Adapun aspek-aspek aktivitas belajar siswa yang dianalisis adalah aspek memperhatikan apa yang disampaikan guru, menjawab pertanyaan guru, membaca LKS yang diberikan guru, meringkas LKS yang diberikan guru, bekerja sama dengan teman pasangan, mempresentasikan hasil ringkasan LKS kepada teman pasangan, dan menanggapi 
hasil ringkasan LKS yang disampaikan teman pasangan. Kegiatan observasi dilaksanakan saat proses pembelajaran menggunakan model Cooperative Script pada pertemuan pertama dan kedua.

Pelaksanaan observasi pertama kali dilakukan pada siswa kelas eksperimen pertemuan pertama dengan menggunakan model Cooperative Script. Berdasarkan hasil observasi aktivitas belajar pada siswa kelas eksperimen pertemuan pertama, sesuai dengan pendapat Armansyah (2014) menyatakan bahwa aspek memperhatikan apa yang disampaikan guru dengan kategori baik karena rata-rata siswa lebih dominan selalu memperhatikan apa yang disampaikan guru, aspek membaca LKS yang diberikan guru dengan kategori baik karena ratarata siswa lebih dominan menjawab sesuai dengan pertanyaan guru, aspek membaca LKS yang diberikan guru dengan kategori cukup karena rata-rata siswa lebih dominan membaca LKS yang diberikan guru dengan baik.

Berdasarkan pemaparan hasil observasi aktivitas belajar pada siswa pada pertemuan pertama dan kedua di atas, dapat disimpulkan bahwa rata-rata aspek aktivitas belajar siswa dengan menggunakan model Cooperative Script pada pertemuan pertama memperoleh nilai rata-rata aktivitas belajar pada pertemuan pertama sebesar $75,33 \%$ dengan kategori cukup. Sedangkan rata-rata aspek aktivitas belajar siswa menggunakan model Cooperative Script pada pertemuan kedua memperoleh nilai rata-rata aktivitas belajar pada kelas eksperimen sebesar 75,94\% dengan kategori cukup. Maka dapat disimpulkan bahwa aktivitas belajar biologi siswa kelas VIII SMP Negeri 7 Lubuklinggau lebih meningkat setelah diberikan perlakuan dengan menggunakan model Cooperative Script. Hal ini sesuai dengan pendapat Boleng (2014) menjelaskan bahwa model Cooperative Script secara signifikan berpengaruh terhadap sikap sosial dan meningkatkan aktivitas belajar, dan hasil belajar kognitif.

\section{SIMPULAN}

Hasil analisis data post-test dengan menggunakan uji-t, diperoleh nilai $t_{\text {hitung }}$ sebesar 2,45. Hasil ini dibandingkan dengan nilai $t_{\text {tabel }}$ pada taraf signifikan

$5 \%$ yaitu 1,67 . Hal ini menunjukkan bahwa nilai $t_{\text {hitung }}(2,45)>t_{\text {tabel }}(1,67)$. Maka dapat ditarik kesimpulan bahwa ada pengaruh model Cooperative Script terhadap hasil belajar biologi siswa kelas VIII SMP Negeri 7 Lubuklinggau.Hasil observasi aktivitas belajar pertemuan pertama diperoleh nilai rata-rata sebesar 75,33\% dengan kategori cukup dan hasil observasi aktivitas belajar pertemuan kedua diperoleh nilai rata-rata sebesar 75,94\% dengan kategori cukup. Maka dapat disimpulkan bahwa aktivitas belajar biologi siswa kelas VIII SMP Negeri 7 Lubuklinggau meningkat setelah diberikan perlakuan dengan menggunakan model Cooperative Script. 


\section{DAFTAR PUSTAKA}

Aqib, Z. (2013). Model-model, Media, dan Strategi Pembelajaran Kontekstual (Inovatif): Bandung. Yrama Widya.

Arikunto, S. (2010). Prosedur Penelitian Suatu Pendekatan Praktik Edisi Revisi 2010: Jakarta. Rineka Cipta.

Armansyah. (2014). Pengaruh Penerapan Model Pembelajaran Cooperative Script terhadap Aktivitas dan Hasil Belajar Siswa pada Mata Pelajaran Biologi Kelas VIII4 SMP Negeri 1 Makassar. Jurnal Nalar Pendidikan, 1(2),66-71.

Boleng, D. T. (2014). Pengaruh Model Pembelajaran Cooperative Script dan ThinkPair-Share terhadap Keterampilan Berpikir Kritis, Sikap Sosial, Aktivitas Belajar dan Hasil Belajar Kognitif Biologi Siswa SMA Multietnis. Jurnal Pendidikan Sains, 2(2),76-84.

Fardila, E. (2013). Pengaruh Strategi Cooperative Script dengan Media Gambar terhadap Motivasi dan Hasil Belajar Biologi Siswa Kelas VII MTS AlRaisiyah Sekarbela Tahun Pelajaran 2013/2014. Jurnal Pendidikan Sains, 2(2), $76-81$.

Hasanah, N. (2013). Perbandingan Hasil Belajar Siswa pada Pembelajaran Cooperative Script dan Artikulasi Materi Gerak Tumbuhan. Jurnal Pendidikan Biologi, 1(3),1-12.

Hidayat, R. (2012). Penerapan Model Pembelajaran Cooperative Script terhadap Hasil Belajar Biologi Siswa Kelas VIII SMPNegeri 1 Makassar. Jurnal Pendidikan Biologi. 1 (2), 1-7.

Natalina, M. (2013). Penerapan Model Pembelajaran Cooperative Script untuk Meningkatkan Aktivitas dan Hasil Belajar Biologi Siswa Kelas VII.5 SMP Negeri 14 Pekanbaru Tahun Ajaran 2012/2013. Jurnal Biogenesis, 10(1),4552.

Nurhidayati, S. (2013). Pengaruh Strategi Cooperative Script dengan Media Gambar Terhadap Motivasi dan Hasil Belajar Biologi Siswa Kelas VII MTs Al-Raisiyah Sekarbela Tahun Pelajaran 2013/2014. Jurnal Pendidikan Sains, 1(5), 6-20.

Purwanto. (2012). Metodologi Penelitian Kuantitatif untuk Psikologi dan Pendidikan: Yogyakarta. Pustaka Pelajar.

Slameto. (2010). Belajar dan Faktor-faktor yang Mempengaruhinya: Jakarta. Rineka Cipta.

Sudjana. (2005). Metoda Statistik: Bandung. Tarsito.

Sugiyanto. (2010). Model-model Pembelajaran: Surakarta. Yuma Pressindo.

Sumiati \& Asra. (2009). Metode Pembelajaran: Bandung. Wacana Prima.

Warouw, M. (2014). Pembelajaran Cooperative Script Metakognitif (CSM) untuk Meningkatkan Hasil Belajar Biologi Siswa SMP di Manado. Jurnal Biogenesis, 1(2),5-18. 